\title{
EKSTRAKSI GELATIN KULIT IKAN TUNA DENGAN PROSES BASA (NaOH)
}

\author{
Rutmin Beatris Pangke ${ }^{1}$, Helen J. Lohoo ${ }^{2}$ dan Agnes T. Agustin ${ }^{2}$ \\ 1) Mahasiswa pada Program Studi Teknologi Hasil Perikanan FPIK Unsrat Manado \\ 2) Staf pengajar pada Program Studi Teknologi Hasil Perikanan FPIK Unsrat Manado \\ Email: rutminpangke@yahoo.co.id
}

\begin{abstract}
Tuna fish skin is an untapped waste properly and it contains collagen that can be made of gelatin manufacture of gelatin from fish skin tuna using alkaline process $(\mathrm{NaOH})$, with the object of knowing the yield of fish skin gelatin tuna (Thunnus albacares) were processed using alkaline $(\mathrm{NaOH})$ .Tuna fish skin gelatin extraction soaking in an alkaline solution $(\mathrm{NaOH})$ at a concentration of $0.3 \%$ and $0.6 \%$ for 48 hours, then the fish skin is washed with running water till a neutral $\mathrm{pH}(6-7)$ and extracted with distilled water at $60^{\circ} \mathrm{C}$.degree for 3 hours. gelatin extract is filtered by the filter cloth and dried in an oven at $60^{\circ} \mathrm{C}$ for 2 days in order to obtain a sheet of gelatin. The extraction of gelatin is then tested the water content and $\mathrm{pH}$, the results of analysis by immersion base solution at a concentration of $0.3 \%$ for 3 hours and extracted at a temperature of $60{ }^{\circ} \mathrm{C}$ to produce gelatin at a concentration of $5.96 \%$ and $4.14 \% 0.6$ produces gelatin. For analysis of the water content at a concentration of $0.3 \%(5.67 \%)$ and a concentration of $0.6 \%(5.17 \%)$, the $\mathrm{pH}$ value obtained in tuna fish skin gelatin treated with alkali $(\mathrm{NaOH}) 0.3 \%(5,98)$ while for the $0.6 \%$ concentration obtained $\mathrm{pH}$ value 6.81 . results gelatin by extraction using an alkaline solution $(\mathrm{NaOH}) 0.3 \%$ more to produce higher yields.
\end{abstract}

\begin{abstract}
Keyword: Gelatin extract $(\mathrm{NaOH})$.
kulit ikan tuna merupakan limbah yang belum dimanfaatkan dengan baik dan didalamnya mengandung kolagen sehingga dapat dibuat gelatin. pembuatan gelatin dari kulit ikan tuna dengan menggunakan proses basa $(\mathrm{NaOH})$, dengan tujuan penelitian mengetahui rendemen gelatin kulit ikan tuna (Thunnus albacares) yang diproses menggunakan basa $(\mathrm{NaOH})$. Ekstraksi gelatin kulit ikan tuna dilakukan perendaman dalam larutan basa $(\mathrm{NaOH})$ dengan konsentrasi $0,3 \%$ dan $0,6 \%$ selama 48 jam, kemudian kulit ikan dicuci dengan air mengalir sampai $\mathrm{pH}$ netral (6-7) dan diekstraksi dengan akuades pada suhu $60^{\circ} \mathrm{C}$ selama 3 jam. ekstrak gelatin disaring dengan kain saring dan dikeringkan dalam oven pada suhu $60^{\circ} \mathrm{C}$ selama 2 hari sehingga diperoleh lembaran gelatin. hasil ekstraksi gelatin ini kemudian diuji kadar air dan pHnya, hasil analisis dengan perendaman larutan basa pada konsentrasi $0,3 \%$ selama 3 jam dan diekstraksi pada suhu $60^{\circ} \mathrm{C}$ menghasilkan gelatin 5,96\% dan pada konsentrasi 0,6 menghasilkan gelatin $4,14 \%$. Untuk analisa kadar air pada konsentrasi $0,3 \%(5,67 \%)$ dan konsentrasi $0,6 \%(5,17 \%)$, nilai $\mathrm{pH}$ yang diperoleh pada gelatin kulit ikan tuna dengan perlakuan basa $(\mathrm{NaOH}) 0,3 \%(5,98)$ sedangkan untuk konsentrasi $0,6 \%$ nilai $\mathrm{pH}$ yang diperoleh (6,81). Hasil gelatin dengan ekstraksi menggunakan larutan basa $(\mathrm{NaOH}) 0,3 \%$ lebih menghasilkan rendemen yang lebih tinggi.
\end{abstract}

Kata Kunci: Ekstraksi Gelatin ( $\mathrm{NaOH})$.

\section{PENDAHULUAN}

Gelatin merupakan suatu jenis protein yang diekstraksi dari jaringan kolagen hewan. Pada hewan kolagen terdapat pada tulang, kulit dan jaringan ikat. Gelatin pertama kali ditemukan oleh orang Perancis yang bernama Papin pada tahun 1682. Penemuan ini kemudian berkembang dan menjadi salah satu bahan industri yang digunakan untuk berbagai keperluan dan saat ini penggunaan gelatin sudah semakin meluas, baik untuk produk pangan maupun non pangan (Astawan, $d k k$. 2002).
Untuk produk pangan gelatin banyak digunakan dimanfaatkan sebagai bahan penstabil (stabilizer), pembentuk gel (gelling agent), pengikat (binder), pengental (thickener), pengemulsi (emulsifier), perekat (adhesive) dan pembungkus makanan yang dapat dimakan (edible coating). Sedangkan pada produk non pangan, gelatin digunakan dalam industri teknik, industri kosmetika, industri fotografi, industri farmasi dan kedokteran (Suryanti, $d k k$. 2006).

Gelatin yang banyak dimanfaatkan adalah berasal dari kulit dan tulang sapi dan babi, bahan-bahan ini menimbulkan masalah 
khususnya untuk negara berpenduduk mayoritas muslim seperti Indonesia karena babi diharamkan untuk dikonsumsi serta isu-isu lain dari hewan mamalia terutama sapi tentang maraknya berita tentang penyakit sapi gila, karena kekhawatiran tersebut maka diperlukan bahan baku alternatif lain yang melimpah murah dan halal yaitu tulang dan kulit ikan sebagai bahan baku sumber gelatin, tulang ikan yang diambil dapat dijadikan sebagai sumber kolagen aman dan halal yang berasal dari limbah industri pengolahan ikan. Pada bagian tertentu dari ikan misalnya tulang dan kulit terdapat kolagen yang diperlukan asam atau alkali dengan metode ekstraksi menyebabkan kolagen tersebut dapat dikonversi menjadi gelatin (Rachmania, 2013).

\section{METODOLOGI PENELITIAN}

\section{Bahan dan Alat}

Bahan utama digunakan dalam penelitian ini adalah kulit ikan tuna (Thunnus albacares) yang di ambil dari PT. Blue Ocean Grace di Kota Bitung, dan bahan lainnya larutan basa $(\mathrm{NaOH})$ dengan konsentrasi basa $(0,3 \%$ dan $0,6 \%)$ dan akuades. Alat yang digunakan untuk penelitian ekstraksi gelatin kulit ikan tuna dengan proses basa $(\mathrm{NaOH})$ yaitu: water bath, oven, desikator, timbangan, kulkas, erlenmeyer, cawan porselin, gelas ukur, baker gelas, penjepit, kain saring, plastik, dan box plastik.

\section{HASIL DAN PEMBAHASAN}

\section{Rendemen}

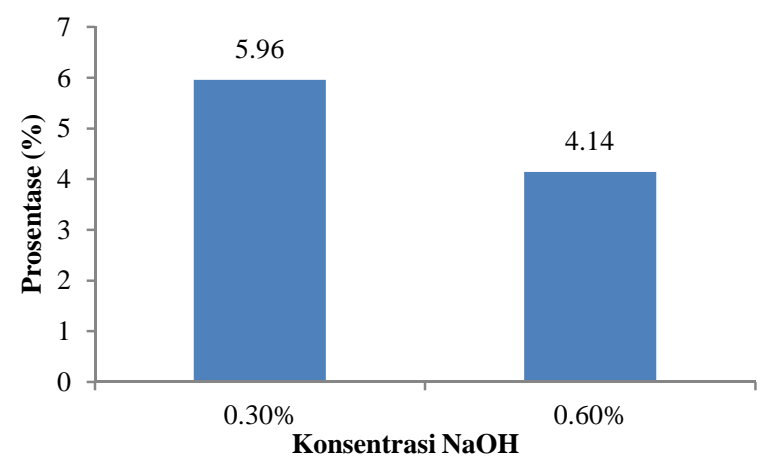

Gambar 1. Rendemen Gelatin Kulit Ikan Tuna.

Nilai rendemen merupakan hasil analisis yang digunakan untuk mengetahui tingkat efisiensi dari proses pengolahan. Rendemen gelatin adalah berat kering yang dihasilkan dari bahan baku kulit yang dalam keadaan bersih diperoleh dari proses ekstraksi. Nilai rendemen kulit ikan tuna.

Berdasarkan gambar 1, dapat dilihat bahwa rendemen gelatin kulit ikan tuna yang diberi perlakuan basa $(\mathrm{NaOH})$ berkisar antara $4,14 \%$ sampai dengan $5,96 \%$. Nilai rendemen tertinggi $5,96 \%$ diperoleh pada perlakuan dengan konsentrasi basa $(\mathrm{NaOH}) \quad 0,3 \%$ sedangkan pada perlakuan konsentrasi basa $(\mathrm{NaOH})$ 0,6\% nilai rendemen yang diperoleh lebih rendah yaitu $4,14 \%$. Rendemen menurun seiring dengan meningkatnya konsentrasi larutan basa $(\mathrm{NaOH})$ yang diberikan. Semakin rendah konsentrasi larutan basa yang ditambahkan semakin besar bobot gelatin kering yang dihasilkan.

Menurut Said, dkk. (2011) menyatakan penggunaan konsentrasi bahan yang tinggi baik asam maupun basa dalam proses produksi gelatin dapat menyebabkan nilai kekuatan gel meningkat maupun menurun sedangkan kualitas gelatin yang dihasilkan dari suatu proses produksi sangat tergantung pada proses ekstraksi yang dilakukan terhadap protein kolagen. Kekuatan gel tertinggi diperoleh pada proses basa pada konsentrasi 9\% dengan lama curing 4 hari. Peningkatan konsentrasi bahan curing dalam proses produksi gelatin dapat menurunkan nilai viskositas, hal ini disebabkan karena bahan curing telah memecah ikatan peptide asam amino menjadi rantai molekul yang sangat pendek sehingga viskositasnya menurun. Dilain pihak peningkatan konsentrasi bahan curing dapat pula meningkatkan nilai viskositas apabila bahan curing mampu memecah ikatan peptide pada ikatan yang tepat dengan molekul lebih panjang.

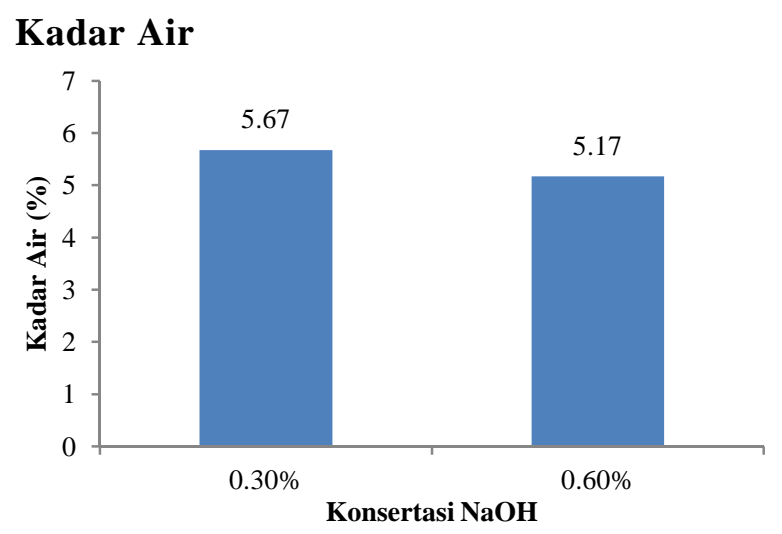

Gambar 2. Kadar air gelatin kulit ikan tuna.

Kadar air dapat mempengaruhi penampakan tekstur, cita rasa serta bahan 
pangan, kadar air gelatin akan berpengaruh terhadap daya simpan karena erat kaitannya dengan aktivitas metabolisme yang terjadi selama gelatin tersebut disimpan seperti aktivitas enzim, aktivitas mikroba dan aktivitas kimiawi, yaitu terjadinya ketengikan dan reaksi-reaksi non enzimatik sehingga menimbulkan perubahan sifat-sifat organoleptik dan nilai mutunya (Rachmania, 2013).

Said, dkk. (2011) menyatakan nilai kadar air gelatin mengalami penurunan secara sangat nyata pada proses basa dibanding proses asam. Hal ini dipengaruhi oleh kinerja bahan curing basa $\left(\mathrm{Ca} \quad(\mathrm{OH})_{2}\right)$ dalam memecah struktur asam amino yang menyusun protein kulit. Struktur asam amino tersebut menjadi sangat lemah hingga akhirnya mengalami proses denaturasi. Proses denaturasi menyebabkan terjadinya perubahan molekul dan jumlah air yang terikat menjadi lebih lemah dan menurun. Akhirnya molekul air mudah lepas sehingga pada saat dilakukan proses pengeringan, nilai kadar air gelatin menjadi lebih rendah. Nilai kadar air melalui proses basa dan asam memenuhi standar mutu sesuai dengan syarat SNI (06-3735-1995), yaitu maksimal $16 \%$.

\section{Nilai pH gelatin}

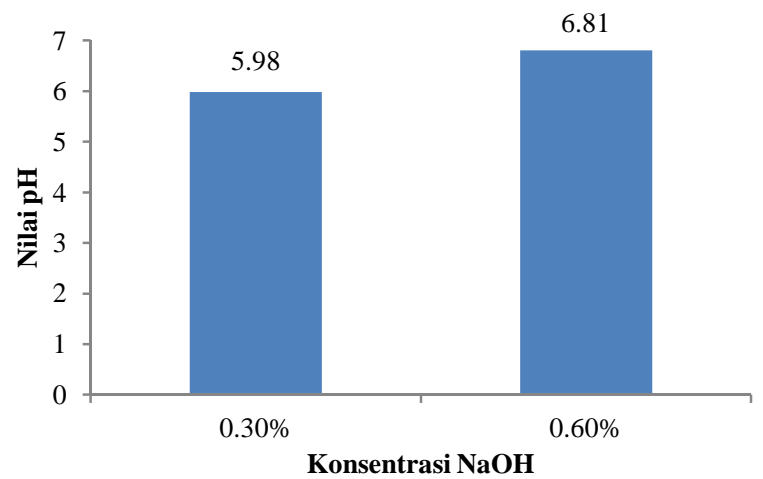

Gambar 3. pH gelatin kulit ikan Tuna.

Nilai pH gelatin berhubungan dengan perlakuan basa yang digunakan dalam proses pembuatannya. Nilai $\mathrm{pH}$ gelatin dengan perlakuan konsentrasi basa $(\mathrm{NaOH})$ yang berbeda disajikan pada gambar 3 .

Pada gambar ini terlihat bahwa nilai $\mathrm{pH}$ gelatin kulit ikan tuna dengan perlakuan larutan basa $(\mathrm{NaOH})$; pada konsentrasi $0,3 \%$ diperoleh pengukuran nilai $\mathrm{pH} 5,98$ dan untuk perlakuan dengan larutan basa $0,6 \%$ diperoleh pengukuran nilai $\mathrm{pH} 6,81$. Nilai $\mathrm{pH}$ yang cenderung basa diduga karena pencucian dengan air secara berulang setelah proses perendaman tidak dapat mengeluarkan semua basa dalam jaringan kolagen kulit ikan sehingga terdapat sisa larutan basa yang terbawah saat ekstraksi, yang akan mempengaruhi tingkat basa pada gelatin yang dihasilkan.

\section{DAFTAR PUSTAKA}

Andarwulan N., F Kusnandar danD. Herawati. 2011. Analisis pangan. Penerbit Dian Rakyat-Jakarta

(AOAC) Assocation of Official Analytical and Chemistry. 1995. Official Methods of Analysis. Penentuan kadar air bahan pangan. pdf. www.googlecendekia.com.

(AOAC). 1990. Official Methods of Analysis. Penentuan kadar derajat keasaman (pH). pdf. www.googlecendekia.com.

Astawan M., Hariyadi P dan Mulyani A. 2002. Analisis sifat reologi gelatin dari kulit ikan cucut. Jurnal Teknologi dan Industri Pangan, vol.XIII no.1, hal. 38.

Dewan Standardisasi Nasional. 1995. SNI 06-3735-1995. Mutu dan Cara Uji Gelatin. Dewan Standardisasi Nasional, Jakarta.

Hastuti D., I. Sumpe. 2007. Pengenalan dan proses pembuatan gelatin, Jurnal Ilmu Pertanian, 8 (1), hal. 39.

Kusumawati R., Tazwir dan A. Wawasto. 2008. Pengaruh perendaman dalam asam klorida terhadap kualitas gelatin tulang kakap merah (Letjanus sp.). Jurnal Pascapanen dan Bioteknologi Kelautan dan Perikanan, 3(1), hal. 66.

Moeljanto. 1992. Pengawetan dan Pengolahan Hasil Perikanan. Penebar Swadaya. Jakarta. 